\title{
Correction to: Upper-Body Post-activation Performance Enhancement for Athletic Performance: A Systematic Review with Meta-analysis and Recommendations for Future Research
}

\author{
Mitchell James Finlay $^{1}$ (D) Craig Alan Bridge $^{1}$ (D) $\cdot$ Matt Greig $^{1}$ (D) Richard Michael Page $^{1}$ (D)
}

Published online: 17 December 2021

(c) The Author(s) 2021

\section{Correction to: Sports Medicine} https://doi.org/10.1007/s40279-021-01598-4

\author{
Abstract, Results, final sentence: This sentence, which \\ previously read:
}

"Sport-specific lighter weighted bat swings and swing-specific isometrics resulted in improved subsequent competition weight bat swing velocities, ranging from $\sim 1.3-3.3 \%$; $\mathrm{ES}=0.16-0.57 . "$

should read:

"Sport-specific lighter weighted bat swings and swing-specific isometrics resulted in improved subsequent competition weight bat swing velocities, ranging from $~ 1.3-4.9 \%$; $\mathrm{ES}=0.16-0.57 . "$

The original article has been corrected.

Open Access This article is licensed under a Creative Commons Attribution 4.0 International License, which permits use, sharing, adaptation, distribution and reproduction in any medium or format, as long as you give appropriate credit to the original author(s) and the source, provide a link to the Creative Commons licence, and indicate if changes were made. The images or other third party material in this article are included in the article's Creative Commons licence, unless indicated otherwise in a credit line to the material. If material is not included in the article's Creative Commons licence and your intended use is not permitted by statutory regulation or exceeds the permitted use, you will need to obtain permission directly from the copyright holder. To view a copy of this licence, visit http://creativecommons.org/licenses/by/4.0/.

The original article can be found online at https://doi.org/10.1007/ s40279-021-01598-4.

Mitchell James Finlay

Finlaym@edgehill.ac.uk

Sports Injuries Research Group, Department of Sport and Physical Activity, Edge Hill University, St. Helens Road,

Ormskirk L39 4QP, Lancashire, UK 